\title{
Government contribution to housing delivery challenges in Ekurhuleni Metropolitan Municipality: An exploration
}

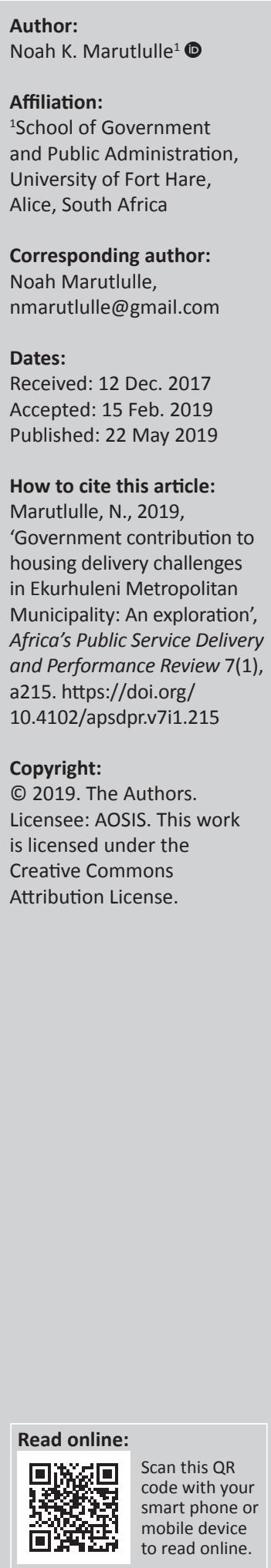

Background: This article examines the government's contribution to housing delivery challenges encountered in Ekurhuleni Metropolitan Municipality (EMM).

Aim: It acknowledges housing shortage, unavailability of land, housing distribution, population growth, corruption, unaffordability and poverty as causes of housing delivery challenges; explores government's contribution to housing delivery challenges in EMM; and seeks to demonstrate government as a key contributory factor in housing delivery.

Setting: The study was conducted in the EMM region.

Methods: The study is exploratory in nature and used qualitative methodology.

Results: Key findings suggest that the government is the dominant cause of the challenges, largely through promises of free housing, economic policies and housing policies that are not conducive to directly tackle existing housing challenges. The findings also suggest that the government plays a major contributory role in each of the causes and that the resolution of the crisis in housing delivery has profound implications for future political stability in the urban areas - EMM to be specific.

Conclusion: The article recommends that there should be a stronger and more concentrated focus on the process of allocation of housing and that the government must play the major role of formulating an effective, and workable coherent housing policy which would trickle further down to municipal levels through provincial and local governments, and having the municipalities adopt targets attached to them as key performance areas on which they would be measured and held accountable.

Keywords: Housing; population growth; contribution; policies; delivery challenges.

\section{Introduction}

Housing is a major place-based infrastructural element and an integral part of the community fabric. It has a profound impact on the social, economic and physical character of a community (Tariq 2012:1). The pervasiveness and spontaneity of the problem of housing has become an everyday discussion in all quarters of the public and private services of the developing countries of Africa (Sokupa 2009:8). In spite of some modest efforts of African governments to provide shelter for their burgeoning population, little new housing is actually being built or improved and most of it that is built remains unaffordable to the great majority of the poor (Storie 2011:25).

In South Africa, it has become increasingly glaring that most of the urban population live in a dehumanising housing environment, while those that have access to average housing do so at abnormal cost (UN-Habitat 2015:31). By May 2010, the national housing backlog was about 2.1 million units, which accounted for about 12 million South Africans who were still in need of better shelter (South Africa Survey 2008/9:582). As of 2018, the backlog was 2.3 million (Msindo 2018), which means that the challenge is an increasing one.

When the present government assumed power in 1994, the majority of South Africans, particularly the disadvantaged in the black, Indian and mixed race communities, believed that life would change for the better and service delivery, particularly housing, would be improved (Jeffery 2010:351). Over two decades later, for hundreds of thousands of people in Ekurhuleni Metropolitan Municipality (EMM), a place to call home remains an elusive dream (Lindsell 2007:81). 


\section{Ekurhuleni Metropolitan Municipality}

Ekurhuleni Metropolitan Municipality is one of the fastest growing areas in South Africa. With a total surface area of $1975 \mathrm{~km}^{2}$ that accommodates a population of 3379104 , Ekurhuleni is spread over $15.6 \%$ of Gauteng's land mass and houses $5.4 \%$ of the country's population, and $25.8 \%$ of Gauteng's population (City of Ekurhuleni Annual Report 2016/2017:12). Ekurhuleni Metropolitan Municipality is popularly known as 'the Gold Axis' for its gold mining activities and it forms the local government of East Rand of which the capital is Germiston and is made up of the following nine towns: Germiston, Alberton, Benoni, Boksburg, Brakpan, Kempton Park or Tembisa, Edenvale, Nigel and Springs. The name Ekurhuleni means 'a place of peace' in Tsonga and the metropolitan municipality is one of the six districts of Gauteng province and one of the eight metropolitan municipalities of South Africa. Its establishment resulted from the restructuring of local government in 2000.

The Ekurhuleni Metropolitan economy is larger and more diverse than those of many of the smaller countries in Africa and accounts for nearly a quarter of the Gauteng economy. Around 7\% of the country's spending power and $7.4 \%$ of the nation's production are located in this area (City of Ekurhuleni Annual Report 2010/2011:7). Many of South Africa's factories for production of goods are located in Ekurhuleni, where manufacturing accounts for just less than $20 \%$ of the gross domestic product (GDP) of Gauteng. Manufacturing in the city accounts for $28 \%$ of total production output. It boasts huge manufacturing industries such as iron and steel, fabricated and metal products, food, machinery, electrical machinery, vehicle parts and chemical products. Because of its largest concentration of industry in the whole of South Africa and in Africa, Ekurhuleni is also often referred to as 'Africa's workshop'. It also boasts a network of roads, airports, rail lines, telephones, electricity grids and telecommunications that rivals those of Europe and America - a first world infrastructure supporting a well-established industrial and commercial complex. It is regarded as the transportation hub of the country.

The municipality is home to OR Tambo International Airport, the busiest airport in Africa which services the entire continent and links to major cities throughout the world. Similarly, many of the world's leading airlines fly into OR Tambo International Airport. More than 14 million passengers pass through this airport each year (City of Ekurhuleni Annual Report 2017/18:33). In addition, a number of smaller domestic airlines connect OR Tambo International Airport with cities throughout South Africa. South Africa's largest railway hub is in Ekurhuleni (Germiston) and links the city to all the major population centres and ports in the Southern African region. A number of South Africa's modern freeways and expressways connect Ekurhuleni to other cities and provinces. The Maputo Corridor development, South Africa's most advanced spatial development initiative, connects Ekurhuleni with the capital of Mozambique and the largest South African Indian Ocean port. Direct rail, road and air links connect Ekurhuleni to Durban, the biggest and busiest port within South Africa. The Blue IQ projects, situated within Ekurhuleni, include the Wadeville-Alrode Industrial Corridor with linkages to the largest logistical hub, the City Deep Container Terminal, the Gautrain rapid rail link to Johannesburg and Tshwane and the OR Tambo International Airport Industrial Development Zone (IDZ) (Ekurhuleni Metropolitan Municipality - Integrated Development Plan and Service Delivery Budget Implementation Plan 2013/14:83).

Ekurhuleni Metropolitan Municipality suffers a high continued demand for housing. In addition to new commercial developments and a fast-growing workforce in the area, the continued housing demand also seems to be driven by the population growth in the area as a result of urbanisation and also migration from other urban areas. This and the aforementioned facts of EMM being the 'Gold Axis' or 'Africa's workshop' do not suggest that migration of people to EMM is solely for job seeking. Other reasons for migration into the city include infrastructure such as health facilities and other issues. Provincial health, education and social security are also often regarded as potential 'pull' factors promoting in-migration to EMM. Illegal immigration from drought-stricken and strife-torn nations in other parts of sub-Saharan Africa is also a contributing factor.

In the post-1990 period, densification of the urban areas led to Ekurhuleni being a highly concentrated urban complex (City of Ekurhuleni Annual Report 2010/2011:7). According to the City of Ekurhuleni Annual Report (2016/2017:60), many of the informal settlements are situated on land unsuitable for housing and well-located land suitable for housing development is not readily available. There are large vacant land parcels in the mining belt around the urban core which cause Ekurhuleni's spatial distribution to be fragmented. This has resulted in an inequitable city and lowdevelopment densities, with historically disadvantaged communities situated on the urban periphery.

\section{Importance of the article}

The importance of this article is that it explores challenges pertaining to a major place-based infrastructural element and an integral part of the community fabric which has a profound impact on the social, economic and physical character of a community (Tariq 2012:1), and highlights the government's contribution to the challenges. A house is not merely a physical shelter (Hablemitoglu, Ozkan \& Purutcuoglu 2010:219), but also a synergic satisfier that influences the satisfaction of all human needs. Furthermore, it proffers recommendations towards the amelioration of the problem.

\section{Background}

The debate over the causes and consequences of and solutions to housing delivery challenges has gained renewed domination and significance in recent years across different walks of life and disciplines. This is because the lack of 
adequate housing not only compromises development, but eventually also constitutes a security threat from myriad social ills that arise from homelessness. In the logic of this argument, homelessness or inadequate housing is therefore retrogressive to the prospects for sustainable livelihoods (Tshitekere 2008:3). In EMM, this coincided with emergence of pockets of demonstrations in response to the government's perceived poor delivery of other services such as water, health and education, delivered by and/or through the metropolitan municipality.

With the house being a place helping to meet basic physiological needs and helping man to maintain his life (Hablemitoglu et al. 2010:214), there are still people in the municipality who do not benefit from the most basic of services - who do not even have decent living conditions, with some resorting to providing their own shelters (shacks) in a spontaneous and unplanned way in sprawling informal settlements (squatter camps). This assertion was corroborated by Streek (2001:5), who maintains that as a result of the shortage of adequate and available shelter, people occupy any vacant land they find and put up shacks in areas without sanitation, infrastructure or social amenities. Communities feel betrayed and let down by the government and the result of this is people losing faith in the government and resorting to violent methods of seeking the government's attention, and some degree of lawlessness (Baloyi 2007:1).

Finding ways to ensure that everybody living in Ekurhuleni has access to adequate shelter is indeed a challenge (City of Ekurhuleni Annual Report 2009/2010:15), and so is the eradication of the housing backlog in the area. This article acknowledges housing shortage, population growth, unavailability of land, housing distribution, corruption, unaffordability and poverty as causes of housing delivery challenges, explores government's contribution to housing delivery challenges in EMM and seeks to demonstrate it as a key contributory factor.

The objective of this study was to investigate these challenges, identify shortcomings and make recommendations to ameliorate the status quo.

The organisation of the article is as follows:

- Introduction - This section set the article in motion and gave a brief description of EMM.

- Background - This section provided the background of the article.

- Literature review - This section reviewed relevant literature with regard to housing delivery challenges faced by EMM and closely investigated the key components causing the housing delivery challenges encountered.

- Methodology - This section states that the article was guided by a qualitative inquiry and provided reasons why.

- Findings - This section presented, analysed and discussed the main findings of the article and linked them to the objective of the article and the literature reviewed.
- Recommendations - This section provided recommendations for the amelioration of housing delivery challenges encountered in EMM.

- Conclusion - This section provided closure of the article by restating the main ideas and arguments and pulling everything together to help clarify the objective of the article.

\section{Literature review}

A research project does not exist in isolation but must build upon what has been performed previously (Terre Blanche, Durrheim \& Painter 2006:19). While there is no housing delivery challenges theory in South Africa (White Paper on Housing 1994:5), let alone in EMM, several research studies (Baloyi 2007; Cloete 1995; Brutus 2002; Eddy 2010; Napier 1993; Power 1993; Setplan 2008) confirm a generally opinionated view that the housing delivery challenges under study are the result of the previous government and its attitude towards a certain group of its citizenry (Neomarxist views). A host of other research studies (Bond 2002; Bonner, Nieftagodien \& Mathabatha 2012; Bradley 2003; Datt 2002; Dyantyi 2007 Habitat \& International Labour Organization [ILO] 1995; Harvey 2000; Khan \& Thring 2003; Knight 2003) reject this view and evidence to support this rejection leans more towards factors such as the present government's policies, the construction industry, population growth, political and economic variables, unaffordability, unavailability of land, municipal administrative issues than the role played by apartheid as a process and also apartheid as a government - as the causes of housing delivery challenges (liberal neo-classical views).

The above statements acknowledge that there are two broad theories that can be attached to housing delivery challenges concurring with Napier's (1993:26) assertions, as follows:

1. Neomarxist theories - When it comes to the housing problem, class conflict is seen to be at the root of the problems that exist.

2. Liberal neo-classical theories - When it comes to the housing problem, government interference is identified as being a major cause of the problems that exist.

In line with the liberal neo-classical theory, this article confirms that while there are other variables such as population growth (including migration, urbanisation and demographics), municipal administrative issues and political and economic factors that cause housing delivery challenges, government is the most dominant contributor to housing delivery challenges encountered by EMM.

\section{Causes of housing delivery challenges in Ekurhuleni Metropolitan Municipality}

Several studies in the literature (Awake 2005; Bonner et al. 2012; Bradley 2003; Jeffery 2010; Malpass 1990; Napier 1993) attribute housing delivery challenges in EMM to the following:

- housing shortage

- population growth 
- unavailability of land

- housing distribution

- corruption

- unaffordability

- poverty.

\section{Housing shortage}

At the centre of the housing problem is a drastic shortage of housing (Napier 1993:21). Housing shortage means that the total number of households exceeds the number of dwellings available (Malpass 1990:5). Harvey (2000:28) concurs in his statement that a housing shortage is present when there is insufficient housing to accommodate the population in an area, when the supply of houses cannot meet the demand. The housing shortage besetting so many countries is not a result of lack of effective demand but is often a direct result of macroeconomic policies and governments' non-housing budgets claiming an ever-increasing share of a reducing pool of finance during a period of worldwide economic austerity (United Nations Habitat \& ILO 1995:3). In EMM, new construction is not keeping pace with demand and as Bradley (2003:85) succinctly puts it, the lack of supply has created a housing shortage which is exacerbated by land-use competition where there may only be space to allow for either slum housing or industrial expansion, but not both. According to the City of Ekurhuleni Annual Report (2010/2011:25) and Baloyi (2007:3), the housing shortage arises as a result of limited land supply as the city cannot overcome physical barriers such as mountain ranges and mine dumps which hamper the construction of houses and also the strict government regulation on available housingconstructible land. While Van der Waldt and Du Toit (1997:380) concur with these assertions, they attribute the cause of housing shortage to population growth.

\section{Population growth}

Most of the challenges that seemingly remained unresolved since 1994 were as a result of EMM amongst other municipalities chasing moving targets (Bonner et al. 2012:176). Jeffery (2010:353) attributes this to inter-provincial migration and the splitting of households into smaller entities. In the same vein, the City of Ekurhuleni Annual Report (2016/2017:83) states that the ever-increasing demand for housing caused by, amongst others, immigration and urbanisation, exacerbates the challenges of dealing with housing backlogs in the city. However, Napier (1993:23) and Poormohammadi (2006:48) argue that the rate of population growth is more a function of natural growth than other aspects such as in-migration to urban areas. Despite stringent influx control measures to curb African urbanisation, Ekurhuleni's population grew steadily towards the end of 1994 (Bonner et al. 2012:150).

The influx of foreigners into Gauteng also compounded the problem, with the majority of them opting to move into EMM as it is the industrial hub of Gauteng with better job prospects. Eddy (2010:3) agrees that migration (the phenomenon of territorial human mobility) continued to place a greater strain on services which led to higher proportions of people living in informal settlements. Natural increase of the population as argued by Napier (1993:2) is another straining factor. The rate of natural increase is highest amongst the poorest communities, which means that the poor will constitute an ever-increasing proportion of the total urban population over the next several years (Napier 1993:22). According to Van der Waldt and Du Toit (1997:380), issues arising from population growth are related to the capacity of Ekurhuleni's limited resources to provide for the peoples' needs and that it (population growth) has a ripple effect on the provision of services including housing. From 1995 to 2005 , for instance, the number of households rose by $45 \%$, making it difficult for the municipality to keep pace with demand despite an impressive delivery of Reconstruction and Development Programme (RDP) homes (Jeffery 2010:353). Mhone and Edigheji (2003:60) concur that progress is being made on the housing front but admit that the backlog far outruns the construction and delivery of housing.

\section{Unavailability of land}

The shortage of housing in EMM is also attributed to the unavailability of land. Efficient assembly and release of appropriately located land for housing is critical to achieving the desired rate of delivery of housing (White Paper on Housing 1994:27). The provincial budgets and expenditure review (2010:71) points out that the National Housing Department attributes declining delivery years after 1994 to the slow release of land for housing by government and unsettling policy shifts, amongst other things. However, Dyantyi (2007:80) and A'bear (2012:5) argue that unavailability of land is the biggest housing delivery constraint in EMM because of dolomite and shallow undermining. This is confirmed by the City of Ekurhuleni Annual Report (2011/2012:189) which states that a total surface area of the EMM area of jurisdiction is underlain by dolomite land that needs to be managed, controlled and developed in accordance with current legislation to prevent the formation of sinkholes and substances that can have a detrimental impact on infrastructure and human life. The situation is further exacerbated by the fact that a $28 \%$ customer growth (237 067 new customers) is expected up to 2025 (City of Ekurhuleni Annual Report 2010/2011:25). While the Housing Development Agency (HDA) is intended to help with the acquisition and release of land, as well as the provision of funding and the unblocking of delivery constraints, and it will also seek to make a wider range of housing choices available including affordable, well-located rental housing (Jeffery 2010:354), the unavailability of land poses a major, insurmountable challenge (City of Ekurhuleni Annual Report 2010/2011:25). Tissington (2011:7) concurs in her view that lack of availability of well-located land and release of public land for development by the government is a major impediment to housing delivery.

\section{Housing distribution}

Housing distribution plays a major role in housing delivery (SA Yearbook 2009/2010:286). The manner in which it is 
being handled by EMM adversely affects the delivery of housing to a greater extent; there is unequal distribution of the available houses to people only aligned or affiliated to a particular political party (Bonner et al. 2012:145). It is the researcher's view that corruption also severely affects housing distribution in that EMM officials get paid in cash or kind by people that are not on the housing waiting list to give them preference over legitimate candidates in the allocation of houses. Some of the people will be coming from areas outside the boundaries of Ekurhuleni. Others would be coming from even as far as outside the borders of South Africa. Such conduct contradicts Cloete's (1997:69) assertion that every public official should display a sense of responsibility when performing official duties; in other words, the conduct should be above reproach. It is for this reason that Musewe (2012:9) emphasises that local government must promote fairness, reasonableness and impartiality and must have no bias. All citizens should be treated equally, with respect and no person, no matter what his or her status is in the community, should be given preferential treatment.

\section{Corruption}

According to Cloete and Mokgoro (1995:137), corruption is a particularly viral form of organisational cancer which once it enters the lifestream of a public agency, quickly spreads to all parts - it is highly contagious, debilitating and costly to treat. Corruption also hinders delivery of affordable housing. The City of Ekurhuleni Annual Report (2016/2017:51) concurs in its statement that corruption breaks down societal norms, erodes good governance and obstructs service delivery. In 2008/2009, the South African Institute of Race Relations documented a litany of fraud offences that state employees committed against the housing department. In 2009, the Gauteng Provincial Government failed to take action against a construction company that had received a R58 million housing tender but had not delivered even a single completed housing unit (South Africa Survey 2008/9:582). According to Nathan (2013:12), because of the hierarchical character of the state and the related lack of accountability of high-level officials to their subordinates and the general public, 'shady' tender deals with private firms and outright theft of state funds and property is the norm.

In EMM, some staff members are involved in corrupt activities that lead to, amongst other variables, people not on housing waiting lists or people who do not qualify for government houses, like foreigners, being granted preference in the allocation of houses. Such conduct contradicts Cloete's (1997:69) assertion that every public official should display a sense of responsibility when performing official duties; in other words, the conduct should be above reproach. Corruption has become widespread, particularly in the granting of housing subsidies, the selection of building contractors and allocation of completed RDP houses (Jeffery 2010:354). Between February 2010 and January 2012, 63 EMM officials had charges of fraud and corruption levelled against them, of which 28 were dismissed and no one was arrested (City of Ekurhuleni Annual Report 2011/2012:189-190).
In 2007, then Deputy President Kgalema Motlanthe acknowledged that corruption in South Africa was far worse than most people realised (Jeffery 2010:30). It is the researcher's view that the government exacerbates the situation by employing a policy of in the worst-case scenario, only suspending from work (or relieving of duties) public servants suspected or found guilty of corruption without initiating jail terms. Burger (2010:2) states that in April 2010, then Minister of Cooperative Government and Traditional Affairs, Mr Sicelo Shiceka admitted that municipalities are riddled with corruption and maladministration. However, despite the admission, no effective measures are put in place to eradicate corruption (Jeffery 2010:354). Ekurhuleni communities are suffering as a result of this.

\section{Unaffordability}

Coupled to the other key contributory factors to housing delivery challenges in EMM is unaffordability by individuals (White Paper on Housing 1994:9). Low income, particularly amongst the R2500-R7500 income group (South Africa Survey 2008/9:582), is the contributing factor to unaffordability. Low incomes of large proportions of South Africa's population imply that many people are unable to afford adequate housing using their own financial resources alone (White Paper on Housing 1994:9). It has become far more difficult for low-income earners to get onto the property ladder (Fife 2007:36). Innes, Kentridge and Perold (1992:181) propounded a view that socio-economic realities are such that even the most modest formal house is beyond the reach of the poor, most of whom live in informal shelters. Jeffery (2010:354) concedes in his statement that the minimum government housing subsidy has been eroded by building inflation and banks are not extending mortgage finance to the very poor, who cannot afford even the cheapest and most rudimentary formal dwelling. However, according to the White Paper on Housing (1994:3), an increased income to lower income groups could have a major impact on the housing sector by converting latent demand for housing into effective demand. The 2010 New Credit Act (NCA) that was apparently designed to protect particularly the poor from excessive indebtedness exacerbates this situation. In a few instances in EMM where there are sites available, once the sites have been chosen and the houses have been built, they need to be serviced with running water and electricity. This in itself is a major problem because if people cannot afford to buy or build the house, then they would almost certainly not be able to afford the cost of water and electricity (Bradley 2003:85). This defeats the object of adequate housing, which according to Mhone and Edigheji (2003:152) refers to a combination of land, services such as the provision of water, the removal of sewage and the financing of these including the building of the house (dwelling) itself. Bond (2002:198) agrees that a house must include sanitary facilities, storm water drainage, a household energy supply (whether linked to grid electricity supply or derived from other sources such as solar energy) and convenient access to clean water. Another predominant cause of unaffordability is poverty (Jeffery 2010:354). 


\section{Poverty}

South African society is largely characterised by extreme poverty (Steenekamp 2012:124), which is the leading social issue in the continuation of sprawling cities. The rate of natural increase is highest amongst the poorest communities, which means that the poor will constitute an ever-increasing proportion of the total urban population over the next many years (Napier 1993:22).

As Sokupa (2009:1) states, government has the responsibility to make policies and laws about the rights and responsibilities of citizens and the delivery of government services. It collects revenue (income) from taxes and is supposed to use this money to provide services and infrastructure that improve the lives of all the people in the country, particularly the poor. At present, millions of South Africans face severe problems in accessing even the most basic services and according to Sokupa (2009:1), many of these ultimately become matters of life and death, particularly with regard to issues of housing. More than one million families still live in shacks without power, often sharing a single tap and a mobile toilet amongst dozens of households (Steenekamp 2012:12).

In many areas of Ekurhuleni, the situation is worse with most of the shack dwellers being evicted by authorities and having their shacks and property destroyed. They are forced to move to new areas where they face even more evictions. The poor are ignored by policy makers only to become the focus of public concern when they threaten property interests or when shacks are demolished (Innes et al. 1992:165). It is thus at moments of stress that the existence of the poor or urban homeless penetrates the public consciousness. Burger (2010:1) points out that in 2009, the country experienced a wave of service delivery protest action across most municipalities including EMM. Lives were lost in the process.

To impact on poverty, a coordinated, multifaceted approach towards initiating and maintaining sustainable socio-economic development is necessary (May, Carter \& Padayachee 2004:47) housing interventions by government can at the most be seen as part of an integrated approach by government to resolve the problem of poverty (White Paper on Housing 1994).

In the light of the foregoing, it is clear that the government plays a contributory role in each of the aforementioned causes. For example, several authors (Baloyi 2007; Bond \& Tait 1997; Jeffery 2010; Knight 2002; Hablemitoglu et al. 2010; Marais 2011) maintain that government regulation, in part, designed to improve quality increased the cost of housing and made it unaffordable. The costs imposed by land-use regulation are particularly pronounced for lesser units to be built. In the same vein, Bhorat and Cassim (2004), Bradley (2003), Burger (2010) and Dyantyi (2007) agree that the government has regulated land use in many ways, including restricting the types of housing built (e.g. apartments vs. single-family homes) as well as dictating the attributes of that housing (e.g. number of garages). While these regulations increased the quality of housing, they drastically reduced the availability of housing by, for example, limiting the total number of housing units produced in a community. While this article acknowledges the foregoing factors as causes of housing delivery challenges in EMM, it is of the view that the government in its individuality is the major contributor to housing delivery challenges encountered in EMM.

\section{Government contribution to housing delivery challenges in Ekurhuleni Metropolitan Municipality}

According to Section 26 of the South African Constitution of 1996, everyone has the right to adequate housing (Balkin \& Rhoden 2003:67). The state must take reasonable legislative and other measures within its available resources to achieve the progressive realisation of each of this right (Republic of South Africa 1996).

When the present government assumed power in 1994, the majority of South Africans, particularly the disadvantaged in the black, Indian and mixed race communities, believed that life would change for the better and service delivery, particularly for essential services such as water and sanitation, electricity, housing, medical and education, would be improved. They believed that the unequal and separate coexistence of population groups across the country which was inextricably connected with the structure and functionality of the previous government regime would finally come to an end. This was heightened by the government's promises of the provision of free housing and free basic services, which encouraged an entitlement mentality and a dependability syndrome that reduced rather than encouraged an impetus to self-help (Jeffery 2010:351) and caused an exponential surge in the expectation of free benefits from government largesse. Furthermore, the inability of millions of poor citizens to acquire marketable skills or regular paid employment left them and still leaves them with no choice but to rely on what the government provides.

More than two decades later, the society is still profoundly bifurcated and for hundreds of thousands of people in Ekurhuleni, the so-called urban underclass, a place to call home remains an elusive dream (Lindsell 2007:81). With the house being a place helping to meet basic physiological needs and helping man to maintain life (Hablemitoglu et al. 2010:214), there are still people in the municipality who do not benefit from the most basic of services - who do not even have decent living conditions, with some resorting to providing their own shelters (shacks) in a spontaneous and unplanned way, in sprawling informal settlements (squatter camps). This assertion was corroborated by Streek (2001:5) who maintains that as a result of the shortage of adequate and available shelter, people occupy any vacant land they find and put up shacks in areas without sanitation, infrastructure or social amenities. This is instigating public demonstrations (Baloyi 2007:6), some of which are rambunctious and extremely violent as communities feel betrayed and let down by the government and its representative bodies, particularly 
municipalities. The result of this is people losing faith in the government and resorting to violent methods of seeking the government's attention and some degree of lawlessness. They only become the focus of public and government concern when they threaten property interests. It is thus only in moments of stress that their existence penetrates the public and government consciousness (Hablemitoglu et al. 2010:214).

Jeffery (2010:34) maintains that part of the problem is that poor households have always interpreted the Constitution's housing mandate as giving them 'a right to a free house'. The Constitution gives the state the task of 'achieving the progressive realisation' of this right, while recognising that it can do so only within the limits of 'its available resources'. However, the finance section of the White Paper on Housing takes a more restrictive view. People are only to receive services that they can afford (Balkin \& Rhoden 2003:67).

\section{Government's promises of free housing}

South Africa's transition to democracy came with various promises from government, amongst them a better life for all with the provision of housing (Sokupa 20099). During the 1994 election campaign, the African National Congress promised to deliver 1 million houses in 5 years. Apart from introducing new housing policy legislation, new institutional arrangements were also created to deal with housing backlogs (Balkin \& Rhoden 2003:67). Section 26 of the Housing Act 1997 (Act 107 of 1997) was formulated in such a manner that a right of 'access to' adequate housing is provided for rather than a right to housing, and that the obligation placed on the state is therefore to create an enabling environment in which individuals are able to realise the right for themselves (Mhone \& Edigheji 2003:151). The RDP contained a set of neo-liberal alongside Keynesian macroeconomic measures which stipulated that the government ought to take the lead in delivering services, housing and infrastructure to the majority poor, mostly black popular classes (Nathan 2013:15). The White Paper on Housing (1994), which also brought neoliberalism to the fore, firmly establishing it as the basic framework, maintains that poor households have the capacity to look after their 'household needs' and that the role of the state should be limited to helping them along the way. Bradley (2003:85) argues that when the present government came into power in 1994, one of the electoral promises it made was that it would endeavour to build a house for every South African. This is in line with the African National Congress' (ANC's) (1994:23) emphasis that housing must be affordable to even the poorest of South Africans. Jeffery (2010:355) argues that the constant emphasis on the government's role in delivering free housing to the poor has sapped an impetus to self-help and bred a strong dependency on the state.

According to Van der Waldt and Du Toit (1997:309), a house means that the individual has responsibility and human dignity. Supplying housing is interrelated with social and economic dynamics which are fundamental to maintaining a person's livelihood and also an expression of the government's resolve to rid the country of poverty and to achieve a better life for all (SA Yearbook 2009/2010:308). As Mhone and Edigheji (2003:152) maintain, adequate housing refers to a combination of land, services such as the provision of water, the removal of sewage and the financing of these, including the building of the house (dwelling) itself. While the government uses section 26 of the Housing Act to absolve itself and its representative bodies including EMM from assuming responsibility for housing delivery challenges (Mhone \& Edigheji 2003:151), full responsibility, in fact, lies squarely with them as section 2 of the Housing Act of 1997 compels all three spheres of government (National, Provincial and Local [EMM]) to give priority to the needs of the poor in respect of housing development (SA Yearbook 2010/2011:296). This assertion is corroborated by The ANC Election Manifesto (ANC 2009:6) which states that as part of social infrastructure development, the ANC government will provide suitably located and affordable housing and decent human settlements to all South Africans, particularly the poor.

\section{Government's economic policies}

Economic growth, poverty reduction and job creation have always been key goals of government economic policy. While several research studies (Barry 2003:2; Bonner et al. 2012:145; Cloete 1995:35; Eddy 2010:3; Malpass 1990:5) maintain that the present government is facing great difficulties and enormous backlogs because of the apartheid legacy to which they solely attribute the present housing delivery challenges, Brutus (2002:1) argues that the problems confronting many citizens today, including those in EMM, are not simply the result of historical factors. The crisis of housing delivery and other basic services is actually a result of the pro-market (growth-oriented) policies adopted by the South African government since 1994, one of the primary goals of which was to reduce inflation and government spending to below $4 \%$ of the GDP, thereby limiting the amount of money the government could spend on social needs including housing (Bradley 2003:85). It is the view of Bonner et al. (2012:207) that from the mid-1990s, South Africa's economic policies were firmly framed within a neoliberal paradigm, which as critics (Bond 2002; Bradley 2003; Datt 2002; Dyantyi 2010; Harvey 2000; Khan \& Thring 2003; Knight 2002; United Nations Habitat \& ILO 1995) point out is characterised by the expansion of opportunities and options for private capital accumulation. Habitat and ILO (1995:1) confirm that in many countries, it has been the policies adopted in response to macroeconomic trends rather than the trends themselves that have resulted in significant declines in shelter investment with a worsening of housing and infrastructure conditions.

Jeffery (2010:255) confirms Bradley's (2003:85) argument that the present government has to a certain extent contributed to the current housing delivery challenges encountered by EMM via its growth-aligned policies including the RDP - aimed at alleviating poverty and reconstructing the economy; Growth, Employment and Redistribution (GEAR) - aimed at rebuilding 
and reshaping the economy in keeping with the goals of the RDP; and Accelerated and Shared Growth Initiative (ASGISA) - aimed at helping the state to attain its core objectives of halving poverty and unemployment by 2014 .

Setplan (2008:38) opines an example substantiating government policies aggravating housing delivery challenges by stating that the trend of settlements continuing to grow and appearing on urban peripheries is exacerbated by policies that promote freehold, single units per 'erf' like the RDP.

While admirable in sentiment, some of government's economic policies gloss municipalities (including EMM) with difficulties of framing an actual policy (Harvey 2000:300). The answer to what a decent home is, for instance, involves a subjective judgement with policy tending to be based on needs rather than on demand. The concept of what is adequate changes over time as peoples' incomes increase and technical improvements such as central heating come about (United Nations Habitat \& ILO 1995:3). Policy has therefore not only to define what is currently decent but also to decide to what extent future minimum requirements should be anticipated. Thus spreading resources thickly on a limited number of houses by councils building to high standards must be balanced against the fact that it extends the time that many people have to continue living in wretched conditions (Harvey 2000:300).

\section{Reconstruction and Development Programme}

Drawing on the Freedom Charter, South Africa's democratic government produced the RDP, a development policy with a socialist resonance (Bond 2002:196). It was aimed at redressing the imbalances of the apartheid legacy by providing decent housing to poor people who were victims of the land segregation policy of the apartheid government. The intention of this programme was to be met by building houses for all people who could not afford them (Bonner et al. 2012:198). The RDP's approach was to ensure that essential service needs were met through vast increases in government subsidies when the market failed and through mobilising additional resources by forcefully topping capital markets and via offbudget methods (Bond 2002:197).

According to the SA Yearbook (2010/2011:296), the South African government made significant progress in meeting the goals of the RDP: providing housing, basic services, health care and land reform that in essence resulted in the lives of millions of people being improved. This view is criticised by Bonner et al. (2012:215) who maintain that the new housing projects are located either in or adjacent to existing African townships, thereby reinforcing apartheid's racial geography. A further criticism of the state's RDP houses is that they are very small, even in comparison to the houses provided by the apartheid government (Bond 2002:197); then minister of Housing and Human Settlement, Tokyo Sexwale, even called them 'ugly little pondokkies'. Jeffery (2010:355) posited that how far the government's housing programme has helped to liberate the poor remains a complex question and agrees that RDP houses (sometimes described by beneficiaries as 'dog kennels') are much smaller than the four-roomed township houses provided by the National Party Government and have often been poorly constructed and badly located.

Ekurhuleni Metropolitan Municipality authorities have admitted that they have few social amenities required for the production of viable communities (Bonner et al. 2012:215). The quality of the RDP houses has often been substandard for various reasons, including the fact that developers were often seen to have come into the low-cost housing market purely to cash in. This is consistent with Marais's (2011:29) criticism of government housing programmes for failing to provide quality, affordable and adequate housing units for the target population. The fact that government was concentrating on quantity of the houses rather than their quality (in the RDP programme) lent itself to a situation where developers would try to cut as many corners as possible (Bradley 2003:85). Thus, while the RDP offered hope for a decent residential existence far beyond what was on offer in existing site-andservice schemes, the actual deliverables were disastrous (Bond 2002:198).

Over the years, it emerged during government-initiated investigations and collapse of many houses that the housing system had been abused and not used for the direct purposes it was intended for. Many contractors had built shoddy houses and did not train people under the people's housing programme (Setplan 2008:41). Knight (2002) contends that government awarded tenders in this programme to contractors who mismanaged them, who did not train people, but allowed them to build houses without proper training. As divulged in the investigation to determine the extent of the damages needed to be fixed by the Department of Housing in its rectification programme, people were not skilled to build houses; hence, all the defects in the houses occurred. Some were found to be unfit to house people and lay unoccupied for several years until they were demolished or collapsed (Jeffery 2010:360).

In discussing the shortcomings of the RDP, Balkin and Rhoden (2003:123) state that the RDP unsuccessfully attempted to reconcile the original Keynesian approach with a set of policy statements and recommendations that were inspired by the neo-liberal framework that had long been the alternative offered, even if in different variants, by big business, the International Monetary Fund and World Bank, and not least, the apartheid government in its twilight years in the form of the Normative Economic Model. Furthermore, in delivering RDP housing the government ignored a key principle of the RDP, namely to promote integrated development. The RDP housing rectification was an ineffective form of redress, having been implemented in a policy context where services were treated primarily as commodities rather than entitlements.

From the above, it can be deduced that the greatest challenge to South Africa's housing crisis which continues to bedevil 
EMM is the systematic failure of government to effectively plan, construct and also to keep records of RDP beneficiaries.

\section{Growth, Employment and Redistribution}

According to Knight (2002), the ability of government to provide housing was restricted by its macroeconomic policy known as GEAR. Two important goals of this policy were to reduce inflation and reduce government expenditure to below $4 \%$ of GDP. This in effect limited the amount which government could spend on social needs including housing.

According to the SA Yearbook (2012/13:9), at its advent GEAR was the best macroeconomic long-term policy to achieve economic growth. However, GEAR was seen by many as being in direct conflict with the goals of the RDP, the reduction of poverty and a more unequal division of wealth (Streek 2001:1). Its impact on families was disastrous as there was little in the way of social security protection for the unemployed, particularly those who had lost their jobs, some of whom lost their houses to banks for failure to make required monthly payments, and others outrightly failed to buy houses as a result of unaffordability. This was a national challenge which also directly affected EMM.

According to the City of Ekurhuleni's (2011:85) admission, GEAR's stringent limits on expenditure limited the ability to meet social development goals of the RDP. As the South African National Housing Code notes:

'The most significant goals of GEAR in respect of the country's capacity to implement the housing programme were those that had to do with availability of funds for housing. GEAR was clear about promising tighter fiscal policy measures, which were brought about by a cut in government expenditure' [- housing included] (Baloyi 2007:6)

\section{Accelerated and Shared Growth Initiative}

Adopted in 2006, the Accelerated and Shared Growth Initiative (ASGI-SA) was a revamped framework for economic growth (Marais 2011:148). Balkin and Rhoden (2003:129) state that the ASGI-SA framework identified an important problem: slow and inequitable growth - and pointed to some key reasons rooted in the inherited economic structure. While many of the proposed solutions had considerable merit, they did not adequately reflect the overall aim of inclusive, shared growth and taken together seemed inadequate to achieve the desired aims, where housing delivery featured but not prominently. While the policy was seen as an improvement in some respects, it largely continued the existing ad hoc, inconsistent and sometimes contradictory approach to key strategic challenges. The absence of a coherent strategy to deal with the critical issues, particularly housing, bedevilled the good intentions of ASGI-SA (Marais 2011:26). As a key government plan for accelerating economic growth, ASGI-SA was too limited in scope, and therefore diverted attention away from the real obstacles to higher growth and also away from addressing issues related to basic needs of the country's citizenry, particularly housing (Deedee 2011:52). According to Marais (2011:26), this was the reason why ASGI-SA was an impediment to housing delivery, as funds that were meant for housing were routed elsewhere.

While ASGI-SA objectives of addressing key economic growth constraints were laudable and correct, it had been launched in concept form only, without any proper implementation plans in place. It lacked 'any compensatory measures to prevent it further exacerbating the country's already alarming trade deficit'. Jeffery (2010:360) maintains that ASGI-SA faced the massive challenge of ensuring adequate support from both inside and outside the state. In terms of the state, a developmental state requires strong central coordination. That means ASGI-SA required a central institution with the capacity to evaluate progress and the power to guide departments, including human settlements, to achieve national aims. Cabinet as a collective lacked the necessary technical backup. Overall, the country needs a strong and united agency to drive economic policy.

\section{Housing policy}

Since 1994, there have been numerous shifts in South African housing policy, which attests both to the socio-economic importance and political imperative of housing provision in the country (Tissington 2011:8). According to Baloyi (2007:8), one key issue is that the housing policy adopted in 1994 has no 'grandfather' clause limiting the provision of housing to those who lived and suffered under the apartheid regime. Furthermore, there is no time limit to the Constitutional clause (Section 26) stating that 'everyone has the right to have access to adequate housing'. South Africans born both before as well as after the end of apartheid thus take the view that 'they have a right to a free house' if their monthly income is below R3500 per month. Accordingly, households continually break themselves up into smaller units in the expectation that each new unit will become entitled to a housing subsidy. National, provincial and local government housing officials referred to this as the growth of an 'entitlement syndrome' and had it that it made the goal of eliminating the housing backlog simply unattainable. Moreover, according to Setplan (2008:39), it was the government itself which had fostered a culture of entitlement and raised 'false expectations'. It was also the government that failed to 'generate enough opportunities for young people', who were often unskilled and unemployed and find it difficult to buy houses for themselves (Deedee 2011:53)

In her discussion about the systemic challenges which have hindered and continue to plague housing policy implementation and consequently the delivery of housing in South Africa and subsequently in EMM, Tissington (2011:8-10) lists the following as some of the government-led causes of housing delivery challenges:

- politicisation of housing delivery at all levels

- dominance of the provinces in housing policy implementation and their underspending of budgets

- underperformance of the Department of Human Settlements

- poor inter- and intra-governmental relations particularly around bulk services connections to housing developments 
- poor coordination between different spheres of government in the housing delivery process, leading to delays in project initiation, approval, implementation and completion

- problems in the allocation of the national budget to local government, particularly around subsidised services such as water, sanitation and electricity

- cost-recovery pressures at the local level which lead to compromised access to basic services for the poor

- technical skills shortages and unwieldy approval procedures with regard to planning and proclamation of land for development

- rampant evictions and shack demolitions by the state and private landlords or owners

- corruption and/or irregular tender processes in the awarding of housing development contracts.

While proponents of the government economic policies (ANC 2009; Department of Housing 2004; Eddy 2010; Ekurhuleni Metropolitan Municipality Integrated Development Plan \& Service Delivery Budget Implementation Plan 2013/14; Ekurhuleni Metropolitan Municipality Integrated Development Plan \& Service Delivery Budget Implementation Plan 2015; The Housing Development Agency 2013) maintain that in devising and implementing the policies, the government had the best interests of its citizens, particularly the poor, at heart, critics (Bonner et al. 2012; Harrison 2013; Jeffery 2010; Storie 2011) argue that one reason why government contributed to the housing problem through the housing policy is largely because the government continued to see informal settlements 'only in negative terms' and had no real interest in their incremental upgrading. It also showed 'very little support for low-income households to build their own homes'; hence, the government gave little space to the poor to participate in either the formulation or implementation of housing policy, while its overwhelming focus remained on the delivery of 'formal' housing at scale. In addition, the housing policy has become much more complicated over time and requires significant capacity to implement, which many local authorities lack. For local authorities to become housing developers, they must first be fully 'accredited' by national government (Provincial budgets and expenditure review 2010:66). To date, this has not occurred.

\section{Methodology}

This article adopted a qualitative methodology because it is phenomenological in nature and also because it concentrates on understanding the full-dimensional picture of the subject of investigation. Qualitative research is a term that denotes the type of inquiry in which the qualities, the characteristics or the properties of a phenomenon are examined for better understanding and explanation (Henning, Van Rensburg \& Smit 2004:5). Moreover, the qualitative approach encouraged an open-ended dialogue between the researcher and the participants, which gave participants the opportunity to respond in their own words rather than having to choose from fixed responses as quantitative methods do.

\section{Findings}

The findings of this article suggest that despite housing delivery challenges in EMM being caused by the housing shortage, population growth, unavailability of land, housing distribution, corruption, unaffordability and poverty, the government is the dominant cause of the challenges largely through promises of free housing, economic policies and housing policies that are not conducive to directly tackle existing housing challenges. The findings also suggest that the government plays a major contributory role in each of the causes and that the resolution of the crisis in housing delivery has profound implications for future political stability in the urban areas - EMM to be specific.

\section{Recommendations}

This article recommends that there should be a stronger, more concentrated focus on the process of allocation of housing. This should include extensive guidelines on how beneficiary waiting lists are developed and the homes are subsequently allocated to these beneficiaries, especially in light of the fact that there is a constant increase in beneficiaries as people migrate more and more to urban areas, EMM in this instance, which results in the government chasing moving targets. The government must play the major role of formulating an effective and workable, coherent housing policy which would trickle further down to municipal levels through provincial and local governments, and having the municipalities adopt targets attached to them as key performance areas on which they would be measured and held accountable. The liberal neo-classical vision that is the bedrock of this article is that in setting out to solve the acute housing shortage by freeing up the housing market, the production of housing will become a major stimulator of economic growth not only in EMM but also in the country, and thus solve many economic problems at the same time (Napier 1993:26) and any other challenges hindering housing delivery in EMM and the country at large.

\section{Conclusion}

In the light of the foregoing, while housing shortage, population growth, unavailability of land, housing distribution, corruption, unaffordability and poverty are causes of housing delivery challenges encountered by EMM, this article concludes that government is the major contributor through its promises of free housing, its housing policy and also a variety of its economic policies. The promises of free housing and the housing policy created within a certain class of citizens a high sense of expectation from the government's largesse and also a dependability syndrome which destroyed any sense of self-reliance or self-sustenance they had. The market-friendly, liberalisation policies the government pursued since 1994 have not delivered the social benefits needed to transform the South African economy and eventually free it from the historical chains of apartheid, with particular regard to housing delivery, to which EMM fell and continues to fall victim. Most poignantly, the RDP, 
GEAR and ASGI-SA were all growth-oriented macroeconomic policies that resulted in reductions in the budget deficit and inflation against the backdrop of diminished expenditures in social votes - housing included. They led to job losses and became threats to access and affordability of basic services including housing. Furthermore, the resources used to finance them, which were intended to help the state attain its core objectives of halving poverty and unemployment by and beyond 2014, also resulted in a decrease in funds intended for social needs, including housing.

\section{Acknowledgements}

This article is a follow-up of the previously published work Obstacles to Housing Delivery in Ekurhuleni Metropolitan Municipality: A Critical Review of Output and Input, published in Africa's Public Service Delivery and Performance Review, Volume 3, Issue 4, 2015 and Causes of informal settlements in Ekurhuleni Metropolitan Municipality: An exploration, published in Africa's Public Service Delivery and Performance Review, Volume 5, Issue 1, 2017.

\section{Competing interests}

The author declares that he has no financial or personal relationships that may have inappropriately influenced him in writing this article.

\section{References}

A'bear, T., 2012, Anchorville gets that sinking feeling, The South African Institute for Engineering and Environmental Geologists, Johannesburg.

African National Congress (ANC), 1994, Reconstruction and Development Programme (RDP): A policy framework, Umanyano Publications, Johannesburg, p. 23.

African National Congress (ANC), 2009, ANC election manifesto, Umanyano Publications, Johannesburg, p. 6

Awake, A., 2005, 'The global housing crisis: Is there a solution?', Monthly publication of Jehovah Witness 3(2), 31.

Balkin, P. \& Rhoden, M., 2003, Housing policy: An introduction, 4th edn., Routledge, New York.

Baloyi, B.V., 2007, Housing delivery in South Africa: A project management case study, viewed 03 January 2013, from https://ujdigispace.uj.ac.za/handle/10210/4425

Barry, M., 2003, 'Peri-urban Tenure Management in South Africa', Marrakeck 2(5), 2.

Bhorat, H. \& Cassim, R., 2004, 'How can the South African Engine become a Ferrari?', Special Report 28(2), 121-124.

Bond, P., 2002, Unsustainable South Africa - Environment, development and socia protest, Merlin Press, London.

Bond, P. \& Tait, A., 1997, 'The failure of housing policy in post-apartheid South Africa', Urban Forum 8(1), 18-21. https://doi.org/10.1007/BF03036607

Bonner, P., Nieftagodien, N. \& Mathabatha, S., 2012, Ekurhuleni - The making of an urban region, Wits University Press, Johannesburg.

Bradley, G., 2003, 'Housing', Black Business Quarterly 6(3), 85.

Brutus, D., 2002, Cost recovery and the crisis of service delivery in South Africa, Human Sciences Research Council Publishers, Cape Town.

Burger, J., 2010, The reason behind service delivery protests in South Africa, viewed 04 June 2011, from http://www.polity.org.za/article

City of Ekurhuleni Annual Report, 2009/2010, EMM human settlements, City of Ekurhuleni, Germiston, p. 15.

City of Ekurhuleni Annual Report, 2010/2011, EMM human settlements, City of Ekurhuleni, Germiston, pp. 7-25.

City of Ekurhuleni Annual Report, 2011/2012, EMM human settlements, City of Ekurhuleni, Germiston, pp. 97-190.

City of Ekurhuleni Annual Report, 2016/2017, EMM human settlements, City of Ekurhuleni, Germiston, pp. 12-60.

City of Ekurhuleni Annual Report, 2017/2018, EMM human settlements, City of Ekurhuleni, Germiston, pp. 10-72.

City of Ekurhuleni, 2011, A ten year history of Ekurhuleni - Housing, 2011, City of Ekurhuleni, Germiston, p. 85.
Cloete, F., 1995, Local government transformation in South Africa, J.L. Van Schaik, Pretoria.

Cloete, J.J.N., 1997, South African Municipal government and administration, J.L. Van Schaik, Pretoria.

Cloete, F. \& Mokgoro, J., 1995, Policies for public service transformation, Juta and Company Limited, Cape Town.

Datt, R., 2002, The human development and economic envelopment, Deep and Deep Publications (Pvt) Ltd, New Delhi.

Deedee, M., 2011, Gauteng Government uses dolomite as reason to evict, South African SDI Alliance, Johannesburg.

Department of Housing, 2004, Breaking new ground: A comprehensive plan for the development of sustainable human settlements, Department of Housing, Pretoria.

Dyantyi, Q.R., 2007, 'A place to call home', Black Business Quarterly 33(3), 71.

Eddy, G., 2010, 'Fast Facts - South African Institute of Race Relations', Economic Growth and Education Are the Keys 9(1), 12-18.

Ekurhuleni Metropolitan Municipality - Integrated Development Plan and Service Delivery Budget Implementation Plan, 2013/14, City of Ekurhuleni, Germiston, p. 83.

Ekurhuleni Metropolitan Municipality - Integrated Development Plan and SDBIP Service Delivery Budget Implementation Plan, 2015, City of Ekurhuleni, Germiston.

Msindo, E., 2018, Housing Backlog: Protests and the demand for housing in South Africa, Public Service Accountability Monitor (PSAM), viewed n.d., from http:// Africa, Public Service Accountability Monitor (PSAM), viewed n.d.
psam.org.za/wp-content/uploads/2016/11/Housing-backlog.pdf

Fife, I., 2007, 'Property inequality - Entry denied,' Financial Mail 192(9), 36.

Hablemitoglu, S., Ozkan, Y. \& Purutcuoglu, E., 2010, 'The assessment of the housing in the theory of Maslow's hierarchy of needs', European Journal of Social Sciences 16(2), 222.

Harrison, B., 2013, 'No hope for Ekurhuleni's Housing backlog', Germiston City News, 18 July, Germiston, p. 13.

Harvey, J., 2000, Urban land economies, 5th edn., Palgrave Publishers, New York.

Henning, E., Van Rensburg, W. \& Smit, B., 2004, Finding your way in qualitative research, Van Schaik, Pretoria.

Innes, D., Kentridge, M. \& Perold, H., 1992, Power and profit: Politics, labour and business in South Africa, Oxford University Press, Cape Town.

Jeffery, A., 2010, Chasing the rainbow: South Africa's move from Mandela to Zuma, Art Publishers, Cape Town.

Khan, F. \& Thring, P., 2003, Housing policy and practice in post-apartheid South Africa, Heinemann Publishers (Pty) Ltd, Sandown.

Knight, R., 2002, 'The Black dispossession in South Africa: The myth of Bantustan independence', Southern Africa Perspectives \& Africa Fund 4(2), 11.

Lindsell, D., 2007, 'A place to call home: Enabling dignified communities', Black Business Quarterly 33(3), 48.

Malpass, P., 1990, The housing crisis, Routledge, London.

Marais, H., 2011, South Africa pushed to the limit: The political economy of change, University of Cape Town Press, Claremont.

May, J., Carter, M. \& Padayachee, V., 2004, 'Is poverty and inequality leading to poor growth?', South African Labour Bulletin 28(2), 18-20.

Mhone, G. \& Edigheji, O., 2003, Governance in the new South Africa: The challenges of globalisation, University of Cape Town Press, Lansdowne.

Musewe, T., 2012, 'Housing our people: Developing adequate housing for Africans,' Mobilitate 15(5), 37.

Napier, M., 1993, 'Housing problem in South Africa - Ideological perspectives', Forum 2(1), 8.

Nathan, O., 2013, Building revolutionary working class counter power: Municipalities, service delivery and protest, Zabalaza, Cape Town.

Poormohammadi, M., 2006, Housing planning, 4th edn., SAMT Publications, Tehran.

Power, A., 1993, Hovels to high rise: State Housing in Europe since 1850, Routledge Publishers, London.

Provincial budgets and expenditure review, 2010, 2003/2004 - 2009/2010, housing, Government Printers, Pretoria, pp. 69-72.

Republic of South Africa, 1996, Constitution of the Republic of South Africa: Act 108 of 1996, Government Gazette no. 17678, 18 December 1996.

Setplan, 2008, Densification framework - status quo: Analysis and findings document for Ekurhuleni Metropolitan Municipality, Settlement Planning Services, City of Ekurhuleni, Johannesburg, pp. 38-68.

Sokupa, T., 2009, 'Let us have better coordination of inter-governmental relations', The Transformer 1(1), pp. 7-10.

South Africa Survey 2008/9, 2009, Living conditions and communications - Housing, South African Institute of Race Relations, Johannesburg.

South Africa Yearbook, 2009/2010, Human settlements, Government Printers, Pretoria, p. 286.

South Africa Yearbook, 2010/11, Human settlements, Government Printers, Pretoria, p. 296.

South Africa Yearbook, 2012/13, Human settlements, Government Printers, Pretoria, p. 9. 
Steenekamp, T., 2012, The South African economy, Oxford University Press, Cape Town.

Storie, M., 2011, Developing a physical vulnerability curve for low income settlements on dolomite in the Gauteng City-Region of South Africa, Global Change and Stability Research Institute, University of Witwatersrand, Johannesburg, pp. 25-31.

Streek, B., 2001, Housing shortage still desperate, viewed 04 June 2011, from http:// mg.co.za/article/2001-06-29-housing-shortage-still-desperate.

Tariq, F., 2012, Facilitating community development with housing microfinance: appraising housing solutions for Pakistan after disasters, College of Design Press, North Carolina State University.

Terre Blanche, M., Durrheim, K. \& Painter, D., 2006, Research in practice, 2nd edn., University of Cape Town Press, Cape Town.

The Housing Development Agency, 2013, Informal settlements status, Government Printers, Pretoria.
Tissington, K., 2011, A resource guide to housing in South Africa 1994-2010: Legislation, policy, programmes and practice, Socio-Economic Rights Institute (SERI), Braamfontein.

Tshitekere, C., 2008, 'The importance of adequate housing', Mail and Guardian, October, p. 7, Johannesburg.

UN-Habitat, 2015, Informal settlements, Report 31 May 2015, Routledge, Taylor \& Francis Group, New York.

United Nations Centre for Human Settlements (Habitat) \& International Labour Organization (ILO), 1995, Shelter provision and employment generation, ILO Publication, Nairobi.

Van der Waldt, G. \& Du Toit, D.F.P., 1997, Managing for excellence in the public sector, Juta and Company Limited, Kenwyn.

White Paper on Housing, 1994, A new housing policy and strategy for South Africa, Government Printers, Pretoria, pp. 1-55. 